\title{
Accounting
}

\section{Corporate governance attributes and firm performance in Saudi Arabia}

\author{
Omar Ali Bagais ${ }^{a}$ and Khaled Salmen Aljaaidia ${ }^{*}$
}

${ }^{a}$ Accounting Department, College of Business Administration, Prince Sattam bin Abdulaziz University, Saudi Arabia

\begin{tabular}{l} 
C H R O N I C L E \\
\hline Article history: \\
Received July 22020 \\
Received in revised format July \\
262020 \\
Accepted July 292020 \\
Available online \\
August 2 2020 \\
\hline Keywords: \\
Corporate governance attributes \\
Performance \\
Saudi Arabia
\end{tabular}

C H R O N I C L E

\section{A B S T R A C T}

The aim of this study is to examine the relationships of audit committee size, audit committee meetings and audit quality with corporate performance among the energy industry in Saudi Arabia using 54 firm-year observations for the period ranging from 2005 to 2018. The Pooled Ordinary-Least Square OLS regression' results indicate that audit committee size was positively associated with corporate performance in the both return on assets (ROA) and return on equities (ROE) models. As for the audit committee meetings, there is a negative relationship with the ROE model, while this relationship has not been reported by the ROA model. In terms of audit quality, there is a positive association reported in both ROA and ROE models. The results documented by this study are important for decision makers at the company and the market levels.

\section{Introduction}

Existing research demonstrates that there is a correlation between corporate governance mechanisms and company performance (Gibson, 2003; Klapper \& Love, 2004; Claessens \& Yurtoglu, 2013; Kao et al., 2019). With regard to this, Kao et al. (2019) stated that the global financial crisis was driven essentially by inadequate corporate governance. Corporate governance mechanisms (e.g. audit quality, board characteristics, etc.) exist for the resolution of any conflict of interest between managers and shareholders and in doing so the enhancement of company performance (Cubbin \& Leech, 1983; Aydin et al., 2007). It has been shown that when a company's managers and shareholders have conflicts of interests and different foci then agency problems can arise (Fama \& Jensen, 1983; Jensen \& Meckling, 1976). The outstanding issues that were brought into focus by financial crises are shareholder alignment, the reduction of conflict of interest with management, and the need for corporate governance to be properly documented for company performance improvement (Al-Twaijry, 2007; Al-Abbas, 2008; AlHamidy, 2010; Al-Moataz \& Basfar, 2010). In today's business world, lenders, investors, regulators, and other stakeholders are increasingly focusing on corporate governance. Corporate governance structures are focused on the ways in which rights and responsibilities are distributed between a company's stakeholders, including shareholders, managers, and Board of Directors; it also encompasses a need for clearly defined rules and procedures governing company decisions. Corporate governance provides a structure that allows companies to establish objectives, undertake performance monitoring, and ultimately achieve their

* Corresponding author

E-mail address: k.aljaaidi@psau.edu.sa (K. S. Aljaaidi)

(C) 2020 by the authors; licensee Growing Science, Canada doi: $10.5267 /$ j.ac.2020.8.005 
objective. A company can be regarded as having a good level of corporate governance if they have a solid system of regulations, board empowerment, high levels of transparency and disclosure, and shareholder rights that are well defined and protected. The purpose of this research is to investigate a correlation between the attributes of audit committees and quality of audits with company performance for energy companies listed in Saudi Arabia between 2005 and 2018.

Companies in developing comments could employ audit committees to monitor and/or bond to mitigate the effect of agency problems (Zhou, Owusu-Ansah \& Maggina, 2018). Researchers report that audit committees can reduce weaknesses in internal control and frequency of restatement for financial statements as well as introducing earnings quality increases (Abbott, Parker, \& Peters, 2004; Klein, 2002; Krishnan, 2005; Zhang, Zhou, \& Zhou, 2007). Audit committees help to establish the distinctiveness of internal audit departments and to ensure that they have sufficient power within an organization for internal auditors to successfully achieve the aims of their audits. An audit committee should make sure that internal audit functions are well organized with proper weight given to employing personnel who are sufficiently professional, competent, and capable.

Audit committees undertake reviews of audit plans, charters, and budgets and approve them; they also make sure that reporting relationships for internal audit staff have no impact on independence. Audit committees should additionally undertake reviews of the range of internal audit procedures and in particular any access restrictions that prevent internal auditors viewing company records, processes, assets, or speaking to personnel when this is a necessary part of the audit. Audit committees also check how appropriate risk assessment methodologies are, decide how frequently audits should take place and how wide-ranging they should be, taking into account the type of company involved, its size, and how complex its operations are. They also check that audits are compliant with internal auditing standards and help internal and external auditors to coordinate. Members of the audit committee should check that they have adequate information regarding the outcomes of internal audits and recommendations and what risks and other implications these have for the company. Audit committees should especially focus on internal dates that assess how company policies are complying with all applicable laws and regulations, how effective internal controls are in crucial fields of operation such as IT, derivatives, investment, claims, underwriting, and accounting, and help management respond and take appropriate remedial action to the findings and recommendations of internal audits, and, ensuring that every finding and recommendation is acted upon efficiently and swiftly. Audit committees should recognize any areas of notable disagreement between internal auditors and management, whether or not resolution has been achieved, for the identification of any influence they may have with audit processes or reports (Kallamu \& Saat, 2015).

Acknowledging how relevant the energy sector is crucial because it is spread over a wider area than just the oil and gas industry. This research intends to offer greater insight into board attributes, corporate governance, and development in Saudi Arabia's energy sector. Reliable energy is a priority for most developing nations, allowing industry and other institutions, including transport, to run smoothly. Developing nations need to establish their financial security through robust monetary standards. Having affordable energy takes a considerable burden off ordinary people. A large number of investors believe that it is crucial that alternative sources of energy are found, as energy can have a huge effect on a nation's economy, taking out considerable capital and labor for production. The energy sector can help to alleviate poverty and improve people's lives. Development goals demand that energy capacity is increased, but this must occur in such a way that the whole society benefits and that the division between the rich and the poor in developing countries is alleviated (Ruti \& Felice, 2013; Yergin \& Gross, 2012).

The rest of the paper continues as follows. The next section briefly discusses the theoretical review and formulation of hypotheses. The third section describes the research methodology. The empirical results and discussions of the study are reported in the fourth section while in the final section, conclusions and implications are drawn.

\section{Literature Review and Hypotheses Development}

The Saudi Code of Corporate Governance requires that any company listed on the Saudi Stock Exchange (Tadawul) has to have an audit committee with a minimum of three members. This is due to the fact that audit committees promote effective monitoring/control and this can enhance company values. It has been demonstrated many times that a competent audit committee can increase available resources, boost efficiency, lower company risk, make crime or fraud less likely, and improve financial reporting (Al-Ghamdi, 2012; Anderson et al., 2004, Archambeault \& DeZoort, 2001; Kalbers \& Fogarty, 1993; Haniffa et al., 2006). Archambeault and DeZoort (2001) demonstrated through empirical research that there is a negative correlation between the size of audit committee and Anderson et al. (2004) and Haniffa et al. (2006) found that there is a negative correlation between audit committee size and debt cost. Raghunandan and Rama (2007) stated that there is a significantly positive correlation between size of audit committee and company performance. Therefore, we expect a significantly positive association between audit committee size and corporate performance.

$H_{1}$ : Audit committee size is positively associated with corporate performance. 
Jensen and Meckling (1976) and Shleifer and Vishny (1997) state that audit committee members should meet frequently when needed for review of investment strategies and to address any possible agency problems. A number of studies in various disciplines have indicated that audit committee meetings are important. Abdul Rahman \& Mohamed Al (2006) and Xie et al. (2003) stated that audit committee meetings have a negative correlation with earnings management. Abbott and Parker (2000) and Beasley et al. (2000) state that audit committee meetings have a positive influence on reductions in fraudulent financial reports. On the same lines, audit committee meetings have been shown to reduce financial misstatements or reporting problems. Anderson et al. (2004) stated that audit committee meeting frequency has a negative correlation with debt costs. KyereboahColeman (2008) states that there is a positive correlation between audit committee meeting frequency and company performance. However, Saleh, Iskandar, and Rahmat (2007) found that audit committee meetings have a negative correlation with company performance because of the extra cost requirements of holding meetings. Based on the above discussion, we expect a significantly positive association between audit committee meetings and firm performance.

\section{$\mathrm{H}_{2}$ : Audit committee meeting is positively associated with corporate performance.}

The correlation between company performance and type of auditor can be predicted using agency theory and the information suppression hypothesis (Jensen \& Meckling, 1976; Fama \& Jensen, 1983). It has been suggested that improved quality of audits leads to lower agency costs and more regulation of opportunistic behavior from management. This, in turn, promotes increases in company value (Grayson, 1999). In accordance with this, a number of empirical studies have stated that there is a positive correlation of company performance and quality of audit (Fan \& Wong, 2005; Aljifri \& Moustafa, 2007; Kao et al., 2019). This makes it likely within the Saudi Arabian environment that external auditors are most likely to positively influence company performance. The testable firm performancehypothesis is described in a direct form:

$H_{3}$ : Audit quality is positively associated with corporate performance.

\section{Research Methodology}

The data in this study were collected form the annual reports of the companies listed in Saudi Stock Exchange (Tadawul). The Data of AC_SIZE, AC_MEET, AU, LASSET, LEV and CF were hand-collected for the period ranging from 2005 to 2018 . The population consists of $\overline{4}$ energy companies listed in Tadawul. The selection of the energy industry is due to the importance of this sector in the Saudi economy. The sample consists of 4 energy companies' data that had been collected for 14 years, resulting in 54 observations after excluding outliers and incomplete data as exhibited in Table 1.

\section{Table 1}

Sample Selection from 20005 to 2018

\begin{tabular}{lc}
\hline Sample & Totals \\
\hline Total listed companies & 4 firms \\
Number of years observed & 14 years \\
Totla observations & 56 \\
Observations discarded (outliers) and incomplete data & $(2)$ \\
\hline Final sample & 54 \\
\hline
\end{tabular}

The economic model is used to develop a model of AC_SIZE, AC_MEET, AU, LASSET, LEV and CP. Since the dependent variable is a continuous, metric scale measurement, to estimate this model, pooled OLS regression is used as follows:

$$
\mathrm{CP}=\beta_{0}+\beta_{1} \text { AC_SIZE }+\beta_{2} \text { AC_MEET }+\beta_{3} \text { AUD }+ \text { Control Variables }+\mathrm{e}
$$

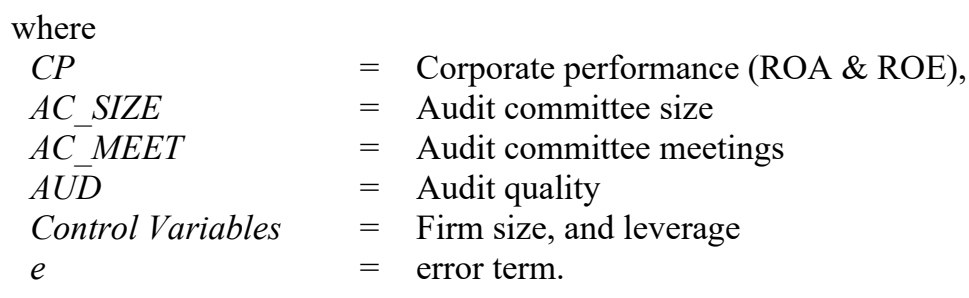

We also control for the effect of two agency-related variables found by the related literature for their potential confounding effect on the CP. It is expected that CP to be positively associated with firm size and leverage (Pfeffer \& Salancik, 1978; Haniffa 
\& Hudaib, 2006; Aljifri \& Moustafa, 2007; Stiglitz and Weiss, 1981; Bhatt \& Bhattacharya, 2017; Mishra \& Kapil, 2017; Saleh et al., 2007). As for the measurements of the variables, Table 2 exhibits the dependent, test and control variables' measurements.

Table 2

Summary of the Operationalization and the Expected Sign of the Research Variables

\begin{tabular}{|c|c|c|c|}
\hline Variables & Acronym & Operationalization & $\begin{array}{l}\text { Coefficient } \\
\text { Predictions }\end{array}$ \\
\hline & & & Pooled OLS \\
\hline \multicolumn{4}{|l|}{ Dependent Variable } \\
\hline Corporate performance & $R O A$ & Net income divided by book value of total assets & d.v \\
\hline Corporate performance & $R O E$ & Net income divided by book value of total equity & d.v \\
\hline \multicolumn{4}{|l|}{ Test Variables } \\
\hline Audit committee size & $A C \_S I Z E$ & the total number of members sitting on the audit committee & + \\
\hline Audit committee meetings & AC_MEET & the number of audit committee meetings during the year & + \\
\hline Audit quality & $\bar{A} U D$ & " 1 " if an auditor is a Big $4, " 0 "$ others & + \\
\hline \multicolumn{4}{|l|}{ Control Variables } \\
\hline Firm Size & LASSET & $\log _{10}$ of total assets & \\
\hline Firm Leverage & LEV & long term debt-to-total asset ratio & \\
\hline
\end{tabular}

\section{Empirical Results and Discussions}

Table 3 shows the descriptive statistics of the variables. It depicts the mean, standard deviation, minimum and maximum of each variable in the sample data set.

Table 3

Descriptive statistics ( $\mathrm{N}=54$ observations)

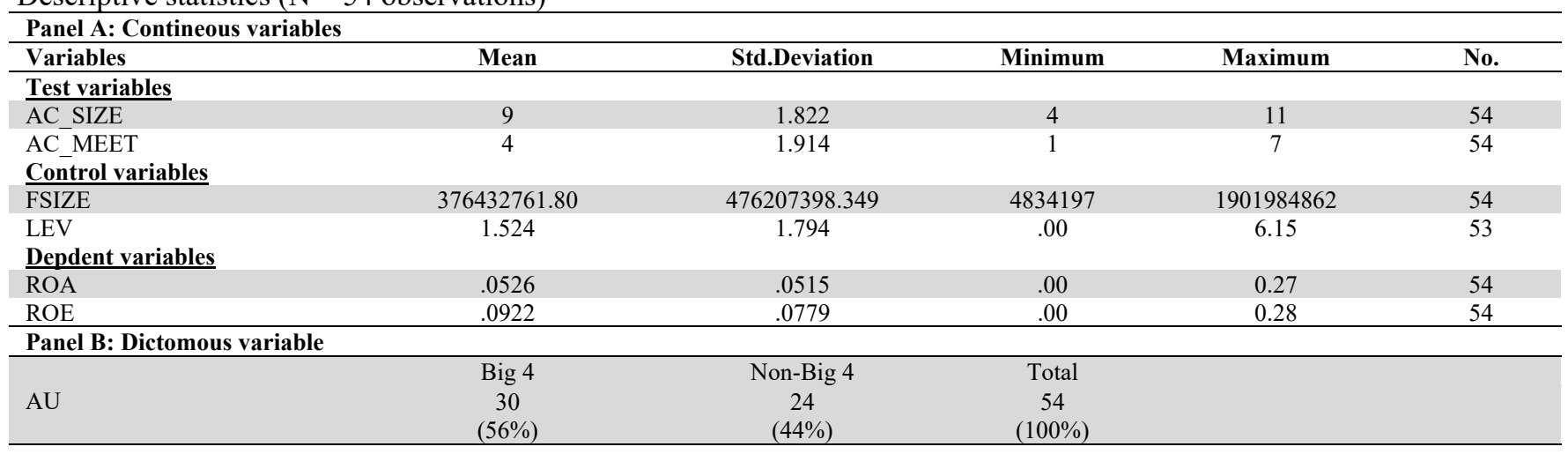

Table 3 displays that there is a significant range of variation among the considered sample of this study. It is shown that the range of $A C \_S I Z E$ is from 4 to 11 with an average of 9 and a standard deviation of 1.822 . The $A C$ MEET ranges from 1 to 7 with a mean of 4 and a standard deviation of 1.914. The LASSET ranges from 4834197 to 1901984862 with an average of 376432761.80 and a standard deviation of 476207398.349. The $L E V$ ranges from .000 to 6.150 with a mean 1.524 and a standard deviation 1.794. The ROA ranges from .000 to .270 with an average of .053 and a standard deviation .052 . The $R O E$ ranges from .000 to .280 with an average .092 and a standard deviation of .078 . As for the $A U, 56 \%$ of the companies are audited by Big 4 audit firms and $44 \%$ are audited by non-Big 4 audit firms.

Table 4

Correlation matrix of independent variables $(\mathrm{N}=54)$

\begin{tabular}{|c|c|c|c|c|c|}
\hline & AC_SIZE & AC_MEET & $\mathrm{AU}$ & LASSET & LEV \\
\hline AC_SIZE & 1 & & & & \\
\hline AC_MEET & $.417 * *$ & 1 & & & \\
\hline $\mathrm{AU}$ & $.495 * *$ & .175 & 1 & & \\
\hline LASSET & $.450 * *$ & .236 & $.337 *$ & 1 & \\
\hline LEV & .219 & -.245 & $.574 * *$ & .175 & 1 \\
\hline
\end{tabular}

The multicollineraity does not exist in this study because the correlation matrixes verify that none of the variables correlates above 0.90 . All the variables have a correlation of equal to or less than .574 . 
Table 5

Model Summary (ROA)

\begin{tabular}{ccccc} 
Model & R & R Square & Adjusted R Square & Std. Error of the Estimate \\
\hline 1 & $.764^{\mathrm{a}}$ & .583 & .537 & .02637 \\
\hline
\end{tabular}

Pooled Ordinary-Least Square (OLS) was used to evaluate the level of effect of the hypothesized variable on the corporate performance using SPSS. Tables from 5 to 10 report the estimated model coefficients, the associated significant test results, the adjusted $\mathrm{R}^{2} \mathrm{~s}$ and the $F$-values for the corporate performance models.

Table 6

ANOVA (ROA)

\begin{tabular}{clccccc}
\hline & Model & Sum of Squares & df & Mean Square & F & Sig. \\
\hline \multirow{3}{*}{1} & Regression & .044 & 5 & .009 & 12.584 & \\
& Residual & .031 & 45 & .001 & \\
\cline { 2 - 7 } & Total & .075 & 50 & & \\
\hline
\end{tabular}

Table 5 shows that the adjusted $R^{2}$ for the $R O A$ is $53.7 \%$. The statistics show that the $R O A$ model has explained $53.7 \%$ of this variance. This indicates a good fit of the each of the corporate performance model (ROA). As shown by Table 6 , the $F$-value for each of the ROA model is statistically significant at the $1 \%$ level, indicating that the overall model can be interpreted.

Table 7

Model Summary (ROE)

\begin{tabular}{ccccc}
\hline Model & $\mathrm{R}$ & R Square & Adjusted R Square & Std. Error of the Estimate \\
\hline 1 & $.761 \mathrm{a}$ & .580 & .535 & .535 \\
\hline
\end{tabular}

Table 7 shows that the adjusted $R^{2}$ for the $R O E$ is $53.5 \%$. The statistics show that the $R O A$ model has explained $53.5 \%$ of this variance. This indicates a good fit of the each of the corporate performance model (ROE).

\section{Table 8}

ANOVA (ROE)

\begin{tabular}{llccccc}
\hline & Model & Sum of Squares & df & Mean Square & F & Sig. \\
\hline \multirow{3}{*}{1} & Regression & .182 & 5 & .036 & 12.960 & \\
& Residual & .132 & 47 & .003 & & \\
\cline { 2 - 7 } & Total & .313 & 52 & & & \\
\hline
\end{tabular}

As shown by Table 8 , the $F$-value for each of the ROE model is statistically significant at the $1 \%$ level, indicating that the overall model can be interpreted.

Table 9

Pooled OLS Analysis Results-ROA $(\mathrm{n}=54)$

\begin{tabular}{|c|c|c|c|}
\hline Variables & Coef. & $\mathbf{t}$ & $\mathbf{P}>|\mathbf{t}|$ \\
\hline \multicolumn{4}{|c|}{ Hypothesized Variables } \\
\hline AC_SIZE & 0.288 & 1.641 & 0.108 \\
\hline AC_MEET & -0.174 & -1.306 & 0.198 \\
\hline AUD & 0.674 & 4.233 & 0.000 \\
\hline \multicolumn{4}{|c|}{ Control Variables } \\
\hline LASSET & -0.145 & -0.977 & 0.334 \\
\hline LEV & -1.058 & -6.707 & 0.000 \\
\hline
\end{tabular}

Adjusted $\mathrm{R}^{2}=53.70$ P-value $=0.000 \mathrm{~F}$-stat $=12.548$

Table 9 shows that audit committee size $A C$ SIZE is positively related to corporate performance CP for $R O A$ model $(p$-value $=$ 0.108 , one-tailed significance). This result is in line with prediction of resource dependence theory and the empirical supported research such as Raghunandan and Rama (2007), Anderson et al. (2004) and Haniffa et al. (2006). Therefore, $\mathrm{H}_{1}$ is accepted. As for audit committee meetings $A C$ MEET and corporate performance CP, a marginal negative association has been documented for ROA model ( $p$-value $=0.198$, one-tailed significance). This result does not give a support for agency and resource dependence theories and the empirical supported research such as Abdul Rahman and Mohamed Al (2006), Xie et al. (2003), Abbott and Parker (2000), Beasley et al. (2000), and Anderson et al. (2004), but it is consistent with Saleh, Iskandar and 
Rahmat (2007). Therefore, $\mathrm{H}_{2}$ is rejected. With regard to the relationship between audit quality $A U$ and corporate performance $\mathrm{CP}$, a positive association was documented for the ROA model ( $p$-value $<0.000$, one-tailed significance). This result is in line with the prediction of the agency theory suggesting that audit quality could lower agency costs, regulate opportunistic management behaviors; hence, grow the value of the firm in the marketplace. Moreover, this result is consistent with the empirical research of (Fan \& Wong, 2005; Aljifri \& Moustafa, 2007; Kao et al., 2019). Therefore, $\mathrm{H}_{3}$ is accepted.

Table 10

Pooled OLS Analysis Results-ROE $(\mathrm{n}=54)$

\begin{tabular}{lccc}
\hline Variables & Coef. & $\mathbf{t}$ & $\mathbf{P}>|\mathbf{t}|$ \\
\hline Hypothesized Variables & & & \\
\hline AC_SIZE & 0.574 & 3.409 & 0.001 \\
AC_MEET & -0.284 & -2.286 & 0.027 \\
AUD & 0.585 & 3.755 & 0.003 \\
Control Variables & & & 0.209 \\
LASSET & -0.182 & -1.274 & 0.000 \\
LEV & -1.015 & -6.567 & \\
\hline
\end{tabular}

Adjusted $\mathrm{R}^{2}=0.535$ P-value $=0.000$ F-stat. $=12.960$

Table 10 shows that audit committee size $A C$ SIZE is positively related to corporate performance CP for $R O E$ model ( $p$-value $<0.000$, one-tailed significance). This result is in line with prediction of agency theory and the empirical supported research such as Raghunandan and Rama (2007), Anderson et al. (2004) and Haniffa et al. (2006). Therefore, $\mathrm{H}_{1}$ is accepted. As for audit committee meetings $A C_{-} M E E T$ and corporate performance CP, a negative association has been reported for ROE model ( $p$ value $=0.027$, one-tailed significance). This result does not give a support for agency and resource dependence theories and the empirical supported research such as Abdul Rahman and Mohamed Al (2006), Xie et al. (2003), Abbott and Parker (2000), Beasley et al. (2000), and Anderson et al. (2004), but it is in line with Saleh, Iskandar and Rahmat (2007). Therefore, $\mathrm{H}_{2}$ is rejected. With regard to the relationship between audit quality $A U$ and corporate performance $\mathrm{CP}$, a positive association was documented for the $R O E$ model ( $p$-value $<0.000$, one-tailed significance). This result is in line with the prediction of the agency theory suggesting that audit quality could lower agency costs, regulate opportunistic management behaviors; hence, grow the value of the firm in the marketplace. Moreover, this result is consistent with the empirical research of (Fan \& Wong, 2005; Aljifri \& Moustafa, 2007; Kao et al., 2019). Therefore, $\mathrm{H}_{3}$ is accepted.

\section{Conclusions and Implications}

This research has examined the influence of corporate performance for Saudi Arabia and companies based on audit committee size, frequency of meetings, and audit quality. According to agency theory, companies that have good governance will show better performance than others. Employing a sample of industrial companies listed on the Saudi Stock Exchange (Tadawul) from 2005 to 2019 (54 companies), it has shown that companies with larger audit committees performed better, and those whose audit committees met more often performed worse. It was also shown that companies hiring external help from the Big Four auditing firms have shown a better level of performance.

These results have a significant message for accounting/auditing regulators, investors, researchers, the stock market, and corporate management. The findings have indicated that the size of audit committee had a positive correlation with company performance and the advisory/resource dependence theory tasks of an audit committee in the Middle East was more significant than their monitoring/oversight tasks. The outcomes also show a negative correlation between frequency of audit meetings and company performance, which shows the negative impact of audit committee members in terms of monitoring/advisory roles. The results show that corporate performance had a positive correlation with quality of audit affirm the value of audit committee members undertaking monitoring.

In the future, research could look at other elements of audit committees, including member qualifications, expertise, and independence, the attributes of the Board of Directors, and classifications of ownership. It would also be useful to undertake the same forms of research in other GCC/Middle Eastern countries.

\section{Acknowledgement}

This publication was supported by the Deanship of Scientific Research at Prince Sattam bin Abdulaziz University, Alkharj, Saudi Arabia. 
Abbott, L. J., \& Parker, S. (2000). Auditor selection and audit committee characteristics. Auditing: A Journal of Practice \& theory, $19(2), 47-66$.

Abbott, L., Parker, S., \& Peters, G. (2004). Audit committee characteristics and restatements. Auditing: A Journal of Practice \& Theory, 23(1), 69-87.

Abdul Rahman, R., \& Mohamed Ali, F. (2006). Board, audit committee, culture and earnings management: Malaysian evidence. Managerial Auditing Journal, 21(7), 783-804.

Al-Abbas, M.A. (2008). Do Saudi companies underestimate us in the application of governance? Aleqtisadia Journal.

Al-Hamidy, A. (2010). The global financial crisis: impact on Saudi Arabia. This volume BIS Papers, $54,347-357$.

Al-Moataz, E., \& Basfar, A. (2010). The role of audit committees in corporate governance: An empirical investigation on Saudi corporations. Journal of King Abdulaziz University: Economics and Administration, 24(2), 193-239.

Al-Twaijry, A. (2007). Saudi stock market historical view and crisis effect: graphical and statistical analysis, Journal of Human Sciences.

Al-Ghamdi, S.A. (2012). Investigation into earnings management practices and the role of corporate governance and external audit in emerging markets: empirical evidence from Saudi Listed Companies (Doctoral dissertation, Durham University).

Anderson, R. C., Mansi, S. A., \& Reeb, D. M. (2004). Board characteristics, accounting report integrity, and the cost of debt. Journal of Accounting and Economics, 37(3), 315-342.

Archambeault, D., \& DeZoort, F. T. (2001). Auditor opinion shopping and the audit committee: An analysis of suspicious auditor switches. International Journal of Auditing, 5(1), 33-52.

Aydin, N., Sayim, M., \& Yalama, A. (2007). Foreign ownership and firm performance: evidence from Turkey. International Research Journal of Finance and Economics, 11(1), 103-111.

Bhatt, R.R., \& Bhattacharya, S. (2017). Family firms, board structure and firm performance: evidence from top Indian firms. International Journal of Law and Management, 59(5), 699-717.

Claessens, S., \& Yurtoglu, B.B. (2013). Corporate governance in emerging markets: a survey. Emerging Markets Review, 15(1), $1-33$.

Cubbin, J., \& Leech, D. (1983). The effect of shareholding dispersion on the degree of control in British companies: theory and measurement. The Economic Journal, 93(370), 351-369.

Fama, E.F., \& Jensen, M.C. (1983). Agency problems and residual claims. Journal of Law and Economics, June, $327-349$.

Gibson, M.S. (2003). Is corporate governance ineffective in emerging markets?. Journal of Financial and Quantitative Analysis, $38(1), 231-250$.

Grayson, M. (1999). Why Do An Audit?. Critical Perspectives on Accounting, 5(10), 630.

Haniffa, R., Yatim, P., Kent, P., \& Clarkson, P. (2006). Governance structures, ethnicity, and audit fees of Malaysian listed firms. Managerial Auditing Journal.

Haniffa, R., \& Hudaib, M. (2006). Corporate governance structure and performance of Malaysian listed companies. Journal of Business Finance \& Accounting, 33(7-8), 1034-1062.

Jensen, M.C., \& Meckling, W.H. (1976), Theory of the firm: Managerial behavior, agency costs and ownership structure. Journal of financial economics, 3(4), 305-360.

Kao, M.F., Hodgkinson, \& L., Jaafar, A. (2019). Ownership structure, board of directors and firm performance: evidence from Taiwan. Corporate Governance: The International Journal of Business in Society, 19(1), 189-216.

Kalbers, L. P., \& Fogarty, T. J. (1993). Audit committee effectiveness: An empirical investigation of the contribution of power. Auditing, 12(1), 24.

Krishnan, J. (2005). Audit Committee financial expertise and Internal Control: An Empirical analysis. The Accounting Review, $80(2), 651$.

Klein, A. (2002). Audit committee, board of director characteristics and earnings management. Journal of Accounting and Economics, 33, 375-400.

Kallamu, B. S., \& Saat, N. A. M. (2015). Audit committee attributes and firm performance: evidence from Malaysian finance companies. Asian Review of Accounting.

Klapper, L.F. \& Love, I. (2004). Corporate governance, investor protection, and performance in emerging markets. Journal of Corporate Finance, 10(5), 703-728.

Kyereboah-Coleman, A. (2008). Corporate governance and firm performance in Africa: A dynamic panel data analysis. Studies in Economics and Econometrics, 32(2), 1-24.

Mishra, R., \& Kapil, S. (2017), Effect of ownership structure and board structure on firm value: evidence from India. Corporate Governance: The International Journal of Business in Society, 17(4), 700-726.

Pfeffer, J.S., \& Salancik, G., (1978). The external control of organizations: a resource dependence perspective. New York.

Raghunandan, K., \& Rama, D. V. (2007). Determinants of audit committee diligence. Accounting Horizons, 21 (3), $265-279$.

Saleh, N. M., Iskandar, T. M., \& Rahmat, M. M. (2007). Audit committee characteristics and earnings management: Evidence from Malaysia. Asian Review of Accounting.

Shleifer, A., \& Vishny, R. W. (1997). A survey of corporate governance. The Journal of Finance, $52(2), 737-783$. 
Stiglitz, J.E., \& Weiss, A. (1981). Credit rationing in markets with imperfect information. The American Economic Review, 71(3), 393-410.

Zhang, Y., Zhou, J., \& Zhou, N. (2007). Audit committee quality, auditor independence, and internal control weaknesses. Journal of Accounting and Public Policy, 26(3), 300-327.

Zhou, H., Owusu-Ansah, S., \& Maggina, A. (2018). Board of directors, audit committee, and firm performance: Evidence from Greece. Journal of International Accounting, Auditing and Taxation, 31, 20-36.

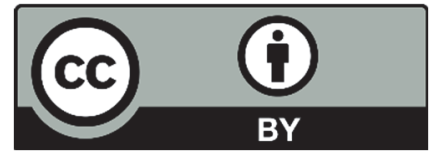

(C) 2020 by the authors; licensee Growing Science, Canada. This is an open access article distributed under the terms and conditions of the Creative Commons Attribution (CC-BY) license (http://creativecommons.org/licenses/by/4.0/). 